\title{
Функціональні зміни показників реоенцефалографії вертебро-базилярних відведень у дівчат-підлітків із діагностованою артеріальною гіпертензією
}

\author{
Тетяна Шевчук, Людмила Апончук, Юлія Корнійчук, \\ Наталія Мазурець, Наталія Руднік
}

Волинський національний університет імені Лесі Українки, Луцьк, Украӥна

Адреса для листування: tetyana_shevchuk_2013@ukr.net

Отримано: 06.09.21; прийнято до друку: 24.11.21; опубліковано: 30.12.21

Резюме. Метою нашого дослідження було визначити особливості мозкового кровообігу на фоні підвищеного артеріального тиску у дівчат-підлітків віком 15-16 років. Для досягнення поставленої мети ми дослідили стан мозкової гемодинаміки у дівчатпідлітків із підвищеним артеріальним тиском та зробили порівняльний аналіз цих показників. Застосували метод варіаційної статистики та методику реоенцефалографії (РЕГ) - метод діагностичного дослідження, що дозволяє проаналізувати найважливіші критерії стану судин головного мозку і руху крові по них, і базується на вимірюванні змін кровонаповнення судин головного мозку вертебро-базилярного басейну. Під час дослідження мозкового кровообігу оцінювали наступні показники реоенцефалографії: період пульсового кровонаповнення, час максимального наповнення, час запізнення реохвилі, амплітуда швидкого наповнення, дикротичний індекс, реографічний індекс, середня швидкість наповнення.

В результаті експерименту було встановлено, що досліджувані показники у дівчат із підвищеним артеріальним тиском (гіпертензісю) характеризуються статистично нижчими значеннями періоду пульсового кровонаповнення (Т), часу максимального наповнення (ax), дикротичного індексу (A1) та достовірно вищою середньою швидкістю наповнення (Vcp) при p $<0,05$. Така зміна показників вказує на зниження об'ємного кровообігу мозкової гемодинаміки, ударного об'єму крові та підвищення тонусу артерій.

Поява підвищеного артеріального тиску у підлітковому віці пов'язана з ризиком збереження його у наступні роки й несприятливим прогнозом до виникнення серцево-судинних захворювань. Тому рання діагностика артеріальної гіпертензії у підлітковому та юнацькому періодах досить актуальна з метою проведення ефективної та своєчасної профілактики й лікування, що дозволить запобігти серйозному прогнозу у зрілі роки. Порушення мозкового кровообігу є важливим компонентом гіпертензійної патології, оскільки багато захворювань мозку супроводжуються саме дисфункцією кровообігу у мозку.

Отримані результати та їх науково-обгрунтований аналіз відіграють важливу роль у клінічній практиці для поглибленого вивчення патогенезу артеріальної гіпертензії, розробки необхідних методів ії профілактики і лікування.

Ключові слова: дівчата-підлітки, артеріальна гіпертензія, мозкова гемодинаміка, реоенцефалографія.

\section{Functional changes in rheoencephalography of vertebro-basilar leads in adolescent girls diagnosed with hypertension}

\section{Tetyana Shevchuk, Lyudmyla Aponchuk, Yuliia Korniichuk, Natalia Mazurets, Natalia Rudnik}

Lesya Ukrainka Volyn National University, Lutsk, Ukraine

Correspondence: tetyana_shevchuk_2013@ukr.net

Abstract. The aim of our study was to determine the features of cerebral circulation on the background of high blood pressure in adolescent girl saged 15-16 years. To achieve this goal, westudied the state of cerebral hemodynamics in adolescent girls with high blood pressure and made a comparative analysis of the seindicators. The method of variation statistics and the method of rheoencephalography (REG) were used - a method of diagnostic research that allows to analyze the most important criteria for the condition of cerebral vesselsand bloodflow through them, and is based on measuring changes in cerebralvessels of the vertebro-basilar basin. The following in dicators of rheoencephalography were evaluated in the study of cerebral circulation: period of pulse blood filling, time of maximum filling, time of delay, amplitude of fast filling, dichroic index, rheographic index, average filling speed. 
As a result of the experiment, it was found that the studied in dicators in girls with high blood pressure (hypertension) are characterized by statistically lower values of pulse blood filling period (T), maximum filling time (s), dichroic index (A1) and significantly higher average filling rate $(\mathrm{Vcp})$ at $\mathrm{p}<0.05$. This change indicates a decrease in cerebral hemodynamic volume, stroke volume of blood and increased arterial tone.

The appearance of high blood pressure in adolescence is associated with the risk of its persistence in subsequent years and an unfavorable prognosis for cardiovascular disease. Therefore, early diagnosis of hypertension in adolescence and adolescence is quite relevant in order to conduct effective and timely prevention and treatment, which will prevent a serious prognosis in adulthood. Cerebrovascular disorders are an important component of hypertension, as many brain diseases are accompanied by circulatory dysfunction in the brain.

The obtained results and their scientifically substantiated analysis play an important role in clinical practice for a more in-depth study of the pathogenesis of arterial hypertension, development of the necessary methods of its prevention and treatment.

Key words: adolescent girls, arterial hypertension, cerebral hemodynamics, rheoencephalography.

\section{ВСТУП}

До недавнього часу вважалось, що артеріальна гіпертензія (АГ) - це проблема дорослого населення, в той час як у дітей та підлітків АГ трапляється нечасто і проявляється в основному як вторинна (симптоматична) гіпертензія, але завдяки впровадженню в педіатричну практику методів вимірювання та нормативних даних артеріального тиску (АТ) з'ясувалось, що кількість дітей з рівнем $\mathrm{AT}$, який перевищує вікову норму, значно більше. Тому сьогодні ми спостерігаємо тенденцію до «омолодження» та хронізації перебігу АГ, що привертає ще більшу увагу медиків та науковців до цієї проблеми. Згідно з літературними даними $[1,3,4$, $6,9]$, спостерігається тенденція до збільшення поширеності гіпертензивних реакцій, особливо серед осіб молодого віку.

За результатами обстеження школярів коледжів, поширеність всіх видів артеріальної гіпертензії, включаючи початкову артеріальну гіпертензію (ПАГ), складає 12,3-30 \% [2, 8]. Тому можна констатувати, що рання діагностика артеріальної гіпертензії є важливою науковою і практичною проблемою.

\section{МАТЕРІАЛИ ТА МЕТОДИ}

Дослідження проведено в лабораторії медикобіологічного моніторингу та громадського здоров'я на кафедрі фізіології людини і тварин факультету біології та лісового господарства Волинського національного університету імені Лесі Українки. Визначення інтенсивності мозкової гемодинаміки проводили за допомогою методу реоенцефалографії, яка базується на вимірюванні змін кровонаповнення судин головного мозку вертебробазилярного басейну. У дослідженні взяли участь дівчата-підлітки віком 15-16 років, яких було поділено на дві групи. I група (основна група) - 10 дів- чат $з$ артеріальною гіпертензією (за даними амбулаторних карток дівчата мали підвищений артеріальний тиск протягом року; початкова стадія гіпертензіi). II група (контрольна група) - 10 дівчат, які є учнями Луцької спеціалізованої загальноосвітньої школи I-III ступенів № 1 (за даними амбулаторних карток - здорові).

Для написання роботи було використано такі показники реоенцефалографії, як період пульсового кровонаповнення $(\mathrm{T}, \mathrm{c})$; час максимального наповнення (ax, c); час запізнення реохвилі (Ra, c); амплітуда швидкого наповнення (Аб, Ом); дикротичний індекс (А1, \%); реографічний індекс (Ах, Ом); середня швидкість наповнення $\left(\mathrm{V}_{\mathrm{cp}}, \mathrm{OM} / \mathrm{c}\right)$.

Статистичну обробку даних здійснювали, застосовуючи статистичний пакет MedStat [5]. Залежно від розподілу даних, що піддаються нормальному чи відмінному від нормального розподілу значень, використовували описову статистику, критерій Стьюдента.

\section{РЕЗУЛЬТАТИ ТА ОБГОВОРЕННЯ}

Аналіз дослідження засвідчив відмінності між значеннями показників мозкової гемодинаміки в обох групах досліджуваних. Для проведення порівняльного аналізу зіставлені значення показників двох груп досліджуваних. Як свідчать результати дослідження, період пульсового коливання (Т), який характеризує стан судин малого та дрібного калібру і час притоку крові до мозку у групі дівчат i3 підвищеним тиском, достовірно нижчий, ніж у контрольній групі досліджуваних. Як видно з таблиці 1, показник Т виявляє тенденцію до збільшення в контрольній групі досліджуваних (II група) при $\mathrm{p}<0,05$, але не несе в собі патологічних змін. Залежно від величини об'ємного пульсового кровонаповнення, цей показник може бути в межах норми, зниженим або підвищеним.

Табличя 1

Параметри реоенцефалограми вертебро-базилярних відведень у дівчат віком 15-16 років $(n=20)$

\begin{tabular}{|c|c|c|c|c|}
\hline Показник & Півкуля & Дівчата І групи (основної групи) & Дівчата контрольної групи & Р \\
\hline $\mathbf{1}$ & $\mathbf{2}$ & $\mathbf{3}$ & $\mathbf{4}$ & $\mathbf{5}$ \\
\hline \multirow{2}{*}{$\mathrm{T}, \mathrm{c}$} & права & $0,71^{*} \pm 0,04$ & $0,92^{*} \pm 0,13$ & $\mathrm{P}<0,05$ \\
\cline { 2 - 5 } & ліва & $0,69^{*} \pm 0,038$ & $0,91^{*} \pm 0,13$ & $\mathrm{P}<0,05$ \\
\hline \multirow{2}{*}{$\mathrm{ax}, \mathrm{c}$} & права & $0,108^{*} \pm 0,017$ & $0,212^{*} \pm 0,14$ & $\mathrm{P}<0,05$ \\
\cline { 2 - 5 } & ліва & $0,102^{*} \pm 0,01$ & $0,226^{*} \pm 0,14$ & $\mathrm{P}<0,05$ \\
\hline \multirow{2}{*}{$\mathrm{Ra}, \mathrm{c}$} & права & $0,158 \pm 0,011$ & $0,164 \pm 0,14$ & $\mathrm{P}>0,05$ \\
\cline { 2 - 5 } & ліва & $0,156 \pm 0,014$ & $0,16 \pm 0,14$ & $\mathrm{P}>0,05$ \\
\hline
\end{tabular}


Закінчення таблииі 1

\begin{tabular}{|c|c|c|c|c|}
\hline $\mathbf{1}$ & $\mathbf{2}$ & $\mathbf{3}$ & $\mathbf{4}$ & $\mathbf{5}$ \\
\hline \multirow{2}{*}{ Аб, Ом } & права & $0,056 \pm 0,027$ & $0,049 \pm 0,01$ & $\mathrm{P}>0,05$ \\
\cline { 2 - 5 } & ліва & $0,063 \pm 0,007$ & $0,053 \pm 0,008$ & $\mathrm{P}>0,05$ \\
\hline \multirow{2}{*}{$\mathrm{A} 1, \%$} & ліва & $89,06^{*} \pm 3,8$ & $94,84^{*} \pm 4,1$ & $\mathrm{P}<0,05$ \\
\cline { 2 - 5 } & права & $85,82^{*} \pm 3,2$ & $134,5^{*} \pm 54$ & $\mathrm{P}<0,05$ \\
\hline \multirow{2}{*}{$\mathrm{Ax}$, Ом } & ліва & $0,089 \pm 0,019$ & $0,091 \pm 0,45$ & $\mathrm{P}>0,05$ \\
\cline { 2 - 5 } & права & $0,12 \pm 0,019$ & $0,096 \pm 0,0098$ & $\mathrm{P}>0,05$ \\
\hline \multirow{2}{*}{$\mathrm{V}_{\mathrm{cp}}$, Ом $/ \mathrm{c}$} & права & $5,4^{*} \pm 0,46$ & $3,7^{*} \pm 0,38$ & $\mathrm{P}<0,05$ \\
\cline { 2 - 5 } & ліва & $5,9 \pm 0,67$ & $16 \pm 13$ & $\mathrm{P}>0,05$ \\
\hline
\end{tabular}

Примітка. *-дані є достовірно відмінні $(p<0,05)$.

Зниження відповідного показника свідчить про значне зниження об'ємного пульсового крово- наповнення, підвищення тонусу артерій розподілу, тобто спостерігається явище гіпертонусу (рис. 1).

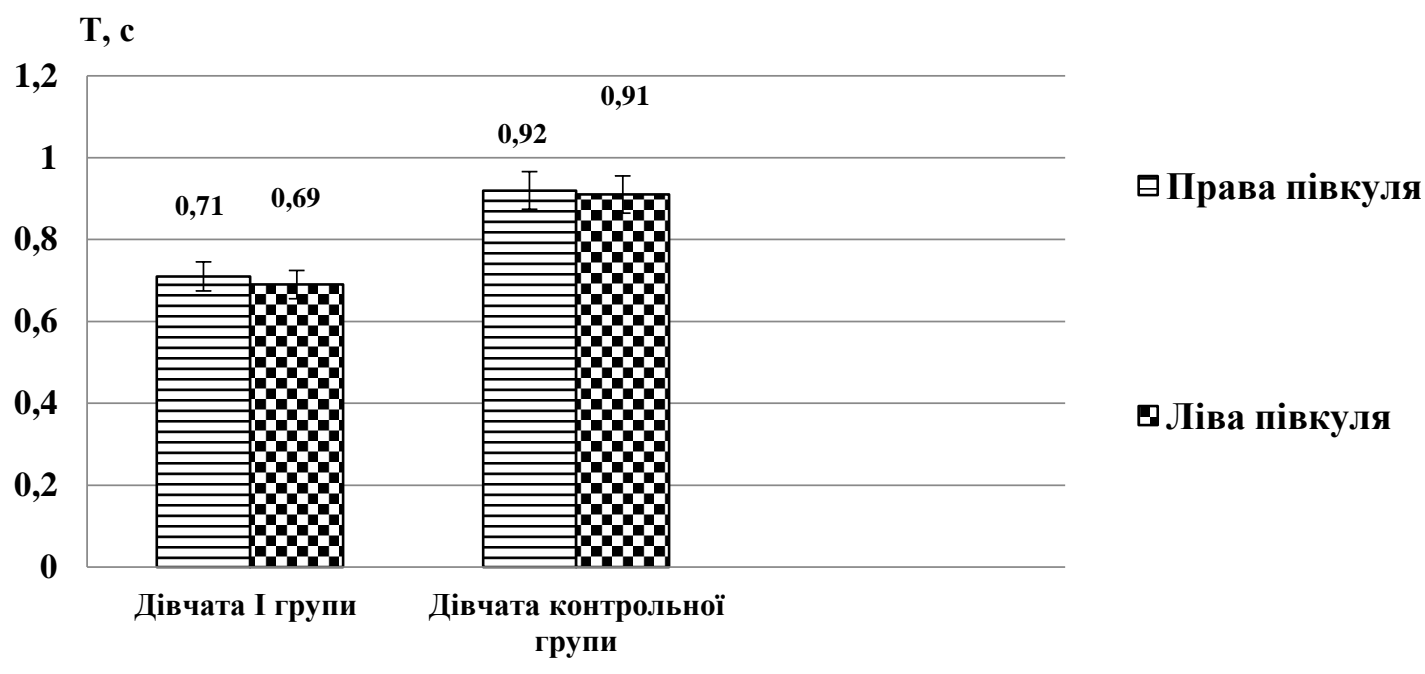

Рис. 1. Період пульсового кровонаповнення (T) у дівчат I і II груп

У досліджуваних дівчат I (основної) групи 3 підвищеним тиском час максимального наповнення (ax), який характеризує тонічний стан судин на відрізку від серця до досліджуваної ділянки [4], має достовірно нижчі значення в обох півкулях головного мозку, ніж у контрольної групи $(\mathrm{p}<0,05)$. У дівчат з I групи спостерігається зниження показника ах в межах фізіологічної норми 0,111-0,127 с (рис. 2). Зниження норми вказує на різницю в тонусі та еластичності артерій і великих судин, а також їх пружність.

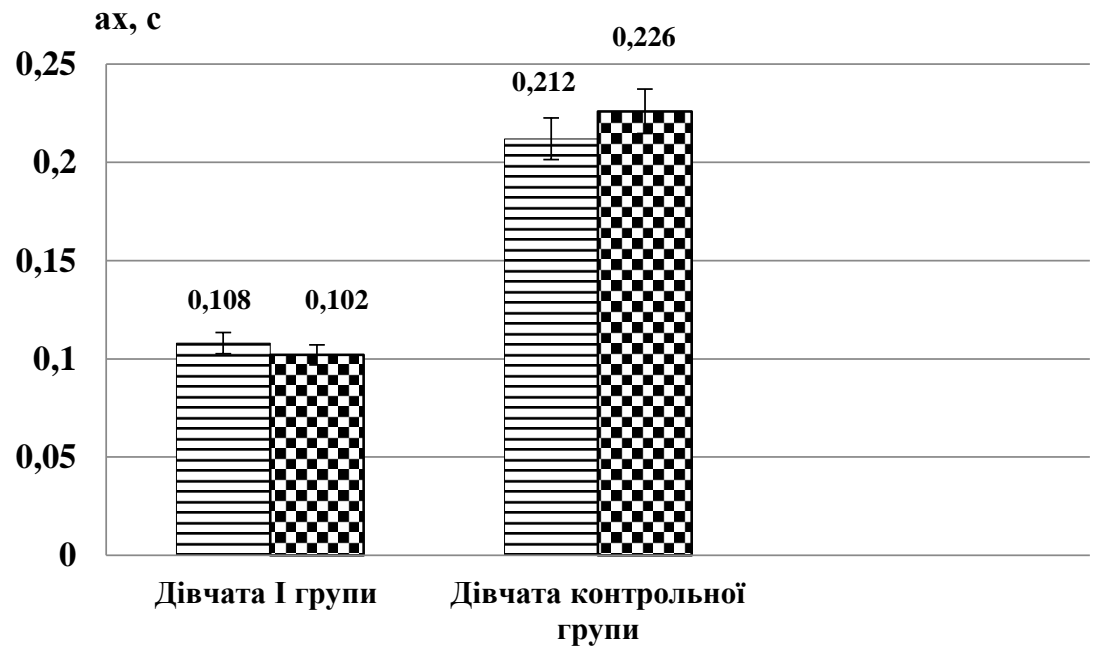

$\boxminus$ Права півкуля

Рис. 2. Час максимального наповнення (аx) у дівчат I i II груп

Реографічним показником, який відображає стан тонусу артерій та стан прекапілярних та пост- капілярних дрібних судин, є дикротичний індекс (A1), який у середньому становить 50 \%. Він част- 
ково залежить від периферійного судинного опору. Підвищення дикротичного індексу (A1) більше 70 \% від норми характеризує підвищення периферич- ного судинного опору або гіперрезистивність судин мікроциркуляторного русла, що ми можемо спостерігати в досліджуваних дівчат при р <0,05 (рис. 3).

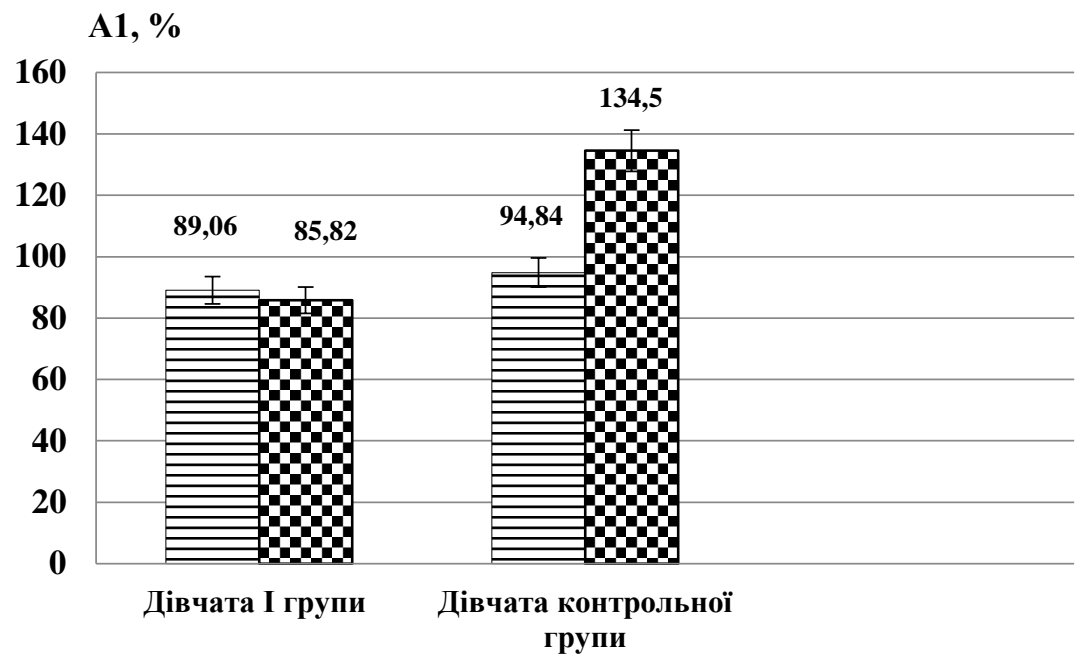

曰Права півкуля

\section{Ф Ліва півкуля}

Pис. 3. Дикротичний індекс (A1) у дівчат I і II груп

У процесі дослідження відзначалась тенденція до збільшення середньої швидкості наповнення $\left(\mathrm{V}_{\mathrm{cp}}\right)$, яка характеризує наповнення середніх і дрібних артерій, що виявляють у дівчат із гіпертензією. $\mathrm{y}$ першої групи $\mathrm{V}_{\mathrm{cp}} \epsilon$ достовірним і на 1 Ом/с $\epsilon$ вищим, ніж у дівчат контрольної групи при $\mathrm{p}<0,05$ (рис. 4). Це свідчить про недостатнє наповнення дрібних, середніх і великих артерій та підвищення тонусу судин мозку.

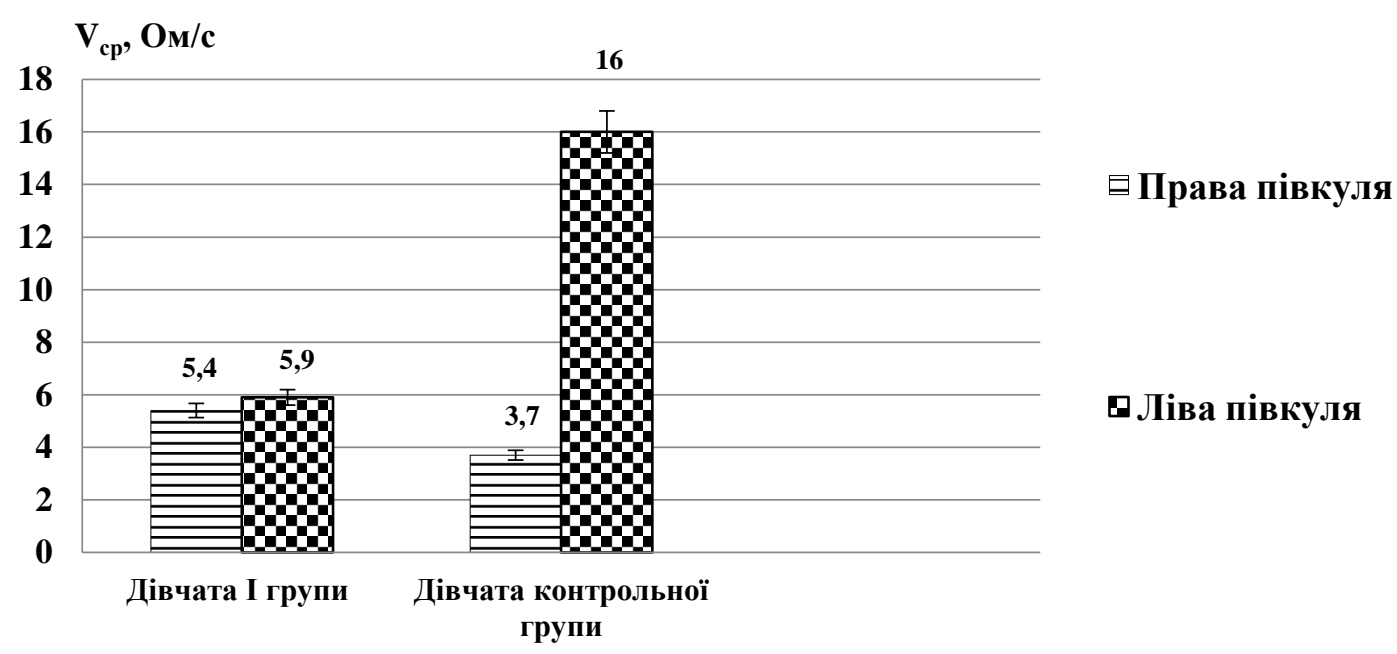

Рис. 4. Середня швидкість наповнення ( $\left.V_{c p}\right)$ у дівчат I і II груп

Час запізнення (поширення) реохвилі (Ra) характеризує тонічний стан судин на відрізку від серця до досліджуваної ділянки. 3 підвищенням судинного тонусу Ra зменшується, а зі зниженням - дещо збільшується. Показник час запізнення реохвилі (Ra) перевищує норму $(0,110-0,120$ c) у дівчат в обох півкулях як контрольної групи, так i дослідної (І групи) і є статистично недостовірним (див. додаток Д). Зменшення цього інтервалу може бути ознакою або підвищення тонусу, або склерозу магістральних судин.

Амплітуда швидкого наповнення (Аб) у всіх досліджуваних $є$ зниженою, але достовірної різниці не зафіксовано при $\mathrm{p}>0,05$ (див. таблиця 1.). Виявлено зниження показника Аб на 50 \% у всіх досліджуваних від норми (0,126-0,142 Ом). Зниження показника Аб свідчить про порушення кровонапов- нення судин головного мозку, що є причиною гіпоксії (кисневого голодування) клітин головного мозку в результаті зменшення кількості кисню, що вдихається, і збільшення насичення крові вуглекислим газом. Амплітуда швидкого наповнення пропорційна до об'єму притоку артеріальної крові в мозок і відтоку венозної крові в момент максимального розтягнення судин. Деякі вчені зазначають $[4,7,10]$, що амплітуда реоенцефалограми залежить від частоти серцевих скорочень, ударного об'єму крові, артеріального тиску і тонусу судинних стінок.

У двох групах не виявлено достовірних відмінностей $(\mathrm{p}>0,05)$ між значеннями реографічного індексу (Ах) - важливого показника, який дає змогу визначати відносне значення пульсового кровонаповнення інтракраніальних судин (див. табл. 1). Ах 
є зниженим у двох групах досліджуваних дівчат (права та ліва півкулі) порівняно 3 нормою $(0,126$ 0,142 Ом), але в основної групи спостерігається більш чітке зниження показника Ах при р >0,05. Ми чітко прослідковуємо, що реографічний індекс менший зліва. Можемо припустити, що це вказує на зниження кровопостачання мозку та зменшення притоку крові в даній ділянці тіла.

За даними реоенцефалографічних досліджень у 90 \% дівчат I групи об’ємний кровотік був зниженим, що зумовлено, ймовірніше за все, наявністю змін у тонусі артерій вертебро-базилярного басейну.

\section{ВИСНОВКИ}

Отже, результати реоенцефалографічних досліджень виявили, що дівчата 3 підвищеним артеріальним тиском (гіпертензією) характеризуються статистично нижчими значеннями показників періоду пульсового кровонаповнення (Т), часу максимального наповнення (ax), дикротичного індексу (A1) та достовірно вищою середньою швидкістю наповнення (Vcp) при $\mathrm{p}<0,05$. Така зміна показників вказує на зниження об'ємного кровообігу мозкової гемодинаміки, ударного об'єму крові та підвищення тонусу артерій.

\section{ЛІТЕРАТУРА}

1. Бойко, Д. О.; Коврига, О. В.; Порохня, Н. Г. Клініко-параклінічна характеристика дітей $з$ первинною артеріальною гіпертензією. Новини і перспективи медичної науки. 2021, c 77-78.

2. Горленко, О. М.; Сочка, Н. В. Визначення імунологічного статусу дітей з ендотеліальною дисфункцією при первинній артеріальній гіпертензії. Проблеми клінічної педіатрії. 2020, $1-2$, c $47-48$.

3. Дебрецені, О. В. Оцінка ефективності вітаміно-мінералокорекції та порівняльна характеристика виявлених порушень у дітей із різних біогеохімічних регіонів із первинною артеріальною гіпертензією. Проблеми клінічної педіатрії. 2020, 1-2, c 49-50.

4. Коренев, Н. М.; Богмат, Л. Ф.; Носова, Е. М. \& и др. Артериальная гипертензия подросткового возраста: распространенность, механизмы формирования, подходы к лечению. Укр. кардіол. журн. 2010, с 57-64.

5. Лях, Ю. Е. Основы компьютерной биостатистики: анализ информации в биологии, медицине и фармации статистическим пакетом MedStat. Донецк, 2006; 211 с.

6. Матюха, Л. Ф.; Орловська, Н. В. \& Бухановська, Т. М. Профілактика розвитку артеріальної гіпертензії у підлітків 3 наявними факторами ризику в умовах сільської амбулаторії. Семейная медицина. 2016, 4(66).

7. Нянковський, С. Л. Стан здоров'я школярів в Україні. Здоровье ребенка. 2012, 5(40), с 109-114.

8. Слабкий, I. О. Характеристика здоров'я дитячого населення України. Современная педиатрия. 2009, 6(28), с 35-40.

9. Товма, А. В.Удосконалення діагностики та прогнозування розвитку ремоделювання лівого шлуночка у підлітків 3 первинною артеріальною гіпертензією. Doctoral dissertation. Запоріжжя, 2020.

10. Шейко, С. О.; Юркова, С.В.Поширеність артеріальної гіпертензії у дітей підліткового віку промислового регіону Криворіжжя. Матеріали XX Національного конгресу кардіологів України (Київ, 25-27 вересня 2019 р.). Український кардіологічний журнал=Ukrainian Journal of Cardiology 26. Дод. 1. 2019, с 181-182. 